\title{
EFEKTIFITAS PENGGUNAAN E-LEARNING BERBASIS EDMODO TERHADAP KEMAMPUAN KOMUNIKASI MATEMATIKA
}

\author{
Vera Dewi Kartini Ompusunggu ${ }^{1)}$ Nilam Sari $^{2)}$ \\ ${ }^{1) 2}$ FKIP, Universitas Quality \\ Email: nasranidua_ompusunggu@yahoo.com
}

\begin{abstract}
ABSTRAK
Seiring dengan berkembangnya teknologi baik secara langsung maupun tidak langsung dapat merubah seseorang dalam berkomunikasi, bersosialisasi dan belajar, hal ini merupakan sebuah tantangan untuk para dosen agar dapat menggunakan teknologi secara optimal dan dapat memudahkan interaksi dengan mahasiswa dalam proses belajar mengajar baik didalam kelas maupun diluar kelas sehingga indikator dalam satuan acara perkuliahan dan rancangan pembelajaran semester dapat tercapai. Edmodo merupakan sebuah platform sosial network bagi dosen dan mahasiswa untuk berbagi ide, file, agenda kegiatan dan penugasan. Edmodo dirancang untuk menciptakan interaksi dosen dan mahasiswa yang menekankan pada komunikasi yang cepat, poling, penugasan, berbagi ide, dan banyak hal lagi. Penelitian bertujuan: 1) untuk mengetahui apakah pembelajaran matematika yang menggunakan Edmodo (eksperimen) lebih baik dibandingkan dengan pembelajaran tanpa menggunakan Edmodo (konvensional) terhadap komunikasi matematika; 2) untuk mengetahui apakah mahasiswa yang belajar dengan menggunakan Edmodo bersikap positif terhadap pembelajaran matematika. Penelitian kuantitatif dengan metode quasi-experiment, desain penelitian yang digunakan adalah nonequivalent control group design: memberikan dua perlakuan yang berbeda terhadap dua kelompok yaitu kelas eksperimen (Edmodo) dan kelas kontrol (konvensional). Teknik pengumpulan dan analisis data kuantitatif dengan menggunakan uji normalitas, uji homogenitas, uji kesamaan dua rata-rata, dan uji t. Hasil penelitian adalah: 1). Pembelajaran yang menggunakan edmodo lebih baik dengan pembelajaran yang tanpa menggunakan edmodo dengan kemampuan komunikasi matematika. 2). Mahasiswa yang belajar menggunakan edmodo bersikap positif terhadap pembelajaran matematika. Implikasi dari penelitian adalah guna peneliti selanjutnya, dengan menggunakan media edmodo maka diperlukan kontrol yang maksimal terhadap mahasiswa. Jika penelitian yang selanjutnya dilakukan dengan sampel yang berbeda maka hasil yang ditunjukkan juga akan berbeda. Hal ini dapat ditinjau dari berbagai macam karakteristik mahasiswa yang berbeda yang sangat mempengaruhi kemampuan komunikasi matematika.
\end{abstract}

\section{Kata Kunci: Efektifitas, E- Learning, Edmodo, Komunikasi Matematika}

\begin{abstract}
Along with the development of technology both directly and indirectly can change someone in communicating, socializing and learning, this is a challenge for lecturers to be able to use technology optimally and to facilitate interaction with students in teaching and learning both in class and outside the classroom so that indicators in the unit of lecture events and semester learning design can be achieved. Edmodo is a social network platform for lecturers and students to share ideas, files, agenda of activities and assignments. Edmodo is designed to create lecturer and student interactions that emphasize fast communication, polling, assignments, sharing ideas, and much more. The research aims: 1) to find out whether mathematics learning using Edmodo (experimental) is better than learning without using Edmodo (conventional) on mathematical communication; 2) to find out whether students who study using Edmodo are positive towards learning mathematics. Quantitative research with quasi-experiment method, the research design used is nonequivalent control group design: providing two different treatments to two groups, namely the experimental class (Edmodo) and the control class (conventional). Quantitative data collection and analysis techniques using normality test, homogeneity test, two average similarity test, and t test. The results of the study are: 1). Learning using edmodo is better with learning without using edmodo with mathematical
\end{abstract}


communication skills. 2). Students who learn to use edmodo have a positive attitude towards learning mathematics. The implication of the research is for the next researcher, using edmodo media so that maximum control is needed on students. If further research is conducted with different samples, the results shown will also be different. This can be viewed from a variety of different characteristics of students that greatly affect the ability of mathematical communication.

\section{Keywords: Effectiveness, E-Learning, Edmodo, Mathematical Communication}

\section{PENDAHULUAN}

E-learning adalah suatu kemajuan penting dalam sistem pendidikan modern. $E$ learning ini membawa pengaruh terjadinya proses transformasi pendidikan konvensional ke dalam bentuk digital, baik secara isi (contents) maupun sistemnya. E-learning adalah suatu jenis belajar mengajar yang memungkinkan tersampaikannya bahan ajar ke siswa dengan menggunakan media Internet, Intranet atau media jaringan komputer lain (Setiawan 2013).

Edmodo dikembangkan pada akhir tahun 2008 oleh Nic Borg dan Jeff Ohara yang berkeyakinan bahwa perlu dikembangkan lingkungan kampus yang terhubung dengan semua aktifitas di dunia. Edmodo adalah platform media sosial yang sering digambarkan sebagai Facebook untuk kampus dan dapat berfungsi lebih banyak lagi sesuai dengan kebutuhan. "Edmodo merupakan aplikasi yang menarik bagi dosen dan mahasiswa dengan elemen sosial yang menyerupai Facebook, tapi sesungguhnya ada nilai lebih besar dalam aplikasi edukasi berbasis jejaring sosial ini”" (Basori 2013)

Peraturan Menteri Pendidikan dan Kebudayaan Republik Indonesia Nomor 49 Tahun 2014 tentang Standar Nasional Pendidikan Tinggi pasal 14 menyebutkan bahwa proses pembelajaran melalui kegiatan kurikuler wajib menggunakan metode pembelajaran yang efektif. Efektif pada peraturan tersebut mempunyai arti bahwa proses pembelajaran harus menggunakan waktu secara optimum dan bersifat kolaboratif. Artinya, interaksi antara dosen dan mahasiswa harus tetap terjaga dan semua materi terinternalisasi dengan baik sesuai dengan waktu yang telah direncanakan. Kriteria yang disampaikan pada peraturan tersebut sebenarnya bisa dicapai dengan memanfaatkan produk TIK atau peran teknologi untuk mendukung proses pembelajaran di dalam kelas.
Fakta di lapangan menunjukkan bahwa proses pembelajaran masih didominasi dengan cara bertatap muka secara langsung (face-to-face), seperti halnya kegiatan perkuliahan yang dilakukan di Pendidikan Guru Sekolah Dasar, Fakultas Keguruan dan Ilmu Pendidikan, Universitas Quality. Hasil observasi yang dilakukan oleh peneliti menunjukkan bahwa model pembelajaran yang dilakukan masih didominasi dengan aktivitas bertatap muka secara langsung. Teknologi sudah berperan di dalam proses pembelajarannya, namun masih belum dominan. Pembelajaran ini yang masih cenderung disebut dengan model pembelajaran konvensional karena peran teknologi masih sangat kecil. Teknologi hanya digunakan untuk mendistribusikan informasi saja, seperti Whatsapp. Survey di lapangan menunjukkan bahwa pembelajaran secara konvensional memiliki kelebihan dan kekurangan.

Berdasarkan pemaparan di atas, pengenalan, dan penggunaan media sosial Edmodo bagi mahasiswa Pendidikan Guru Sekolah Dasar di Universitas Quality dalam proses belajar mengajar sangatlah tepat untuk dilakukan. Keterampilan penggunaan media sosial yang dimiliki oleh mahasiswa tentu akan sangat mempermudah proses pembelajaran dengan menggunakan Edmodo yang memiliki keunggulan serupa dengan aplikasi E-Learning pada umumnya serta ingin dilihat efektifitas dari penggunaan edmodo itu terhadap komunikasi matematika pada mahasiswa tersebut.

Edmodo adalah pembelajaran berbasis jejaring sosial yang aman dan gratis dalam memudahkan dosen untuk membuat dan mengelola kelas virtual sehingga mahasiswa dapat terhubung dengan teman sekelas dan dosen kapan saja dan dimana saja. Edmodo dikembangkan oleh Nicolas Borg and Jeff O'Hara sebagai platform pembelajaran untuk berkolaborasi dan terhubung antara mahasiswa dan dosen dalam berbagi konten pendidikan 
mengelola proyek atau tugas dan menangani pemberitahuan setiap aktivitas.

Edmodo adalah platform pembelajaran sosial untuk dosen, mahasiswa dan orang tua. Dosen juga mampu memposting nilai, tugas dan kuis kepada mahasiswa. Mahasiswa dapat mengirimkan pekerjaan rumah dan melihat nilai dan komentar mereka. Dosen mungkin telah memposting tentang tugas mereka. Dosen juga bisa membuat jajak pendapat dan topik posting untuk diskusi diantara para mahasiswa. Dosen bisa membedakan dan mengindividualisasikan pembelajaran melalui penciptaan subkelompok. Dalam kursus setelah setiap periode kursus selesai dosen tutup keluar jaringan dan buat yang baru untuk kursus berikutnya.

Edmodo adalah platform pembelajaran gratis dan aman yang tersedia di www.edmodo.com. Website ini terlihat mirip dengan facebook, tapi jauh lebih pribadi dan aman untuk lingkungan belajar. Penelitian ini bertujuan untuk selidiki bagaimana seorang dosen non-digital-pribumi dapat menggunakan edmodo untuk mengatur dan menjalankan secara online. Komunitas kelas bagi muridmuridnya untuk bekerja secara online bersamaan dengan kelas fisik mereka, dan untuk laksanakan sebuah lokakarya tentang edmodo untuk dosen lainnya.

Tujuan penggunaan media edmodo dalam pembelajaran dapat dijelaskan sebagai berikut:

a. Meningkatkan kualitas pembelajaran mahasiswa

b. Mengubah budaya mengajar guru

c. Mengubah belajar mahasiswa yang pasif kepada budaya belajar aktif, sehingga terbentuk belajar mandiri.

d. Memperluas kesempatan belajar bagi mahasiswa

e. Mengembangkan dan memperluas produk dan layanan baru

Berdasarkan uraian diatas, dapat disimpulkan bahwa media pembelajaran edmodo membantu dosen untuk memperkuat rencana pelajaran.

1. Fitur Edmodo

Dalam mendukung proses pembelajaran, edmodo dilengkapi dengan beberapa aktivitas pembelajaran, seperti quiz, assignment, poll, grade book, library, award badges, dan parent code. Untuk bahan ajar, edmodo mendukung bahan ajar berupa file dan links ( Kamarga, 2011:267). Penjelasan mengenai fitur edmodo adalah sebagai berikut:

a. Assignment. Fitur ini digunakan oleh dosen untuk memberikan penugasan kepada mahasiswa secara online. Fitur ini dilengkapi dengan waktu deadline dan fitur attach file sehingga mahasiswa dapat mengirimkan tugas dalam bentuk file secara langsung kepada dosen.

b. File dan Links. Fitur ini digunakan oleh dosen dan mahasiswa untuk mengirimkan pesan dengan melampirkan file dan link pada grup kelas. File yang dilampirkan berlaku untuk semua jenis ekstensi seperti doc, pdf, ppt, xls, dll.

c. Quiz. Fitur ini digunakan untuk memberikan evaluasi secar online baik berupa pilihan ganda, isian singkat, maipun soal uraian. Quiz hanya dapat dibuat oleh dosen, sedangkan mahasiswa hanya mengerjakannya saja. Fitur ini dilengkapi dengan batas waktu pengerjaan, informasi tentang kuis yang akan dibuat, judul kuis dan tampilan kuis.

d. Polling. Fitur ini digunakan oleh dosen untuk dibagikan kepada mahasiswa untuk mengetahui tanggapan mahasiswa mengenai hal tertentu yang berkenaan dengan matakuliah.

e. Gradebook. Fitur ini digunakan oleh dosen sebagai catatan nilai mahasiswa yang dapat diisi secar manual atau secara otomatis sedangkan untuk mahasiswa, dapat melihat berupa rekapan nilai dalam bentuk grafik dan penilaian langsung.

f. Library. Fitur ini digunakan oleh dosen maupun mahasiswa sebagi tempat penyimpanan berbagai sumber pembelajaran dengan konten yang bergam. Dosen dapat mengupload bahan ajar, materi, presentasi, sumber referensi, gambar, video, audio, dan konten digital lainnya. File and link yang terdapat di library dapat dibagikan baik kepada mahasiswa maupun grup.

g. Award Badges. Fitur ini digunakan oleh dosen untuk memberikan suatu penghargaan baik kepada mahasiswa maupun kelompok. 
h. Parents Codes. Fitur ini berfungsi memberi kesempatan kepada orangtua/wali masing-masing mahasiswa dapat bergabung memantau aktivitas belajar dan prestasi putra-putrinya, dosen harus mengakses kode untuk orangtua mahasiswa dan kemudian membagikannya pada masing-masing orangtua/wali. Akses kode untuk orangtua mahasiswa dapat diperoleh dengan mengklik nama kelas.

\section{METODE PENELITIAN}

Jenis penelitian adalah penelitian eksperimen semu (quasy eksperiment research). Penelitian eksperimen semu (quasy eksperiment research) yaitu suatu penelitian yang dilakukan berdasarkan suatu percobaan pura-pura dimana kelompok control tidak dapat berfungsi sepenuhnya mengontrol variable-variabel luar yang mempengaruhi pelaksanaan eksperimen yang sebenarnya ("[PDF] Sugiyono Metode Penelitian Kuantitatif Kualitatif Dan $\mathrm{r}$ d - Free Download PDF" n.d.). Peneliti juga tidak dapat melakukan pengendalian variable secara penuh karena subjek penelitian secara alami telah terbentuk dalam suatu kelompok yang utuh, seperti kelompok mahasiswa dalam satu kelas.

Fokus penelitian ini adalah efektifitas penggunaan e-learning berbasis edmodo terhadap kemampuan komunikasi matematika pada mahasiswa pendidikan guru sekolah dasar Universitas Quality. Tujuan dari penelitian ini untuk mengetahui efektifitas penggunaan e-learning berbasis edmodo terhadap komunikasi matematika pada mahasiswa pendidikan guru sekolah dasar Universitas Quality.

Rancangan penelitian ini menggunakan pre-test-post-test control group design. Penelitian ini membagi sasaran penelitian menjadi dua kelas sebagi sampel yaitu kelas eksperimen (Edmodo) dan kelas kontrol (konvensional) dimana power point sebagai media pembelajaran. Materi yang diajarkan pada kelas eksperimen maupun control adalah sama yaitu profesi kependidikan.

Penelitian ini menggunakan pendekatan kuantitatif dan kualitatif dalam pengumpulan datanya, dimana pendekatan kualitatif digunakan untuk menjabarkan dan menjelaskan efektifitas pembelajaran e- learning berbasis edmodo terhadap komunikasi matematika setelah dilakukannya proses pembelajaran. Penelitian ini juga menggunakan pendekatan kuantitatif dalam mengukur komunikasi mahasiswa dari ranah kognitif dengan menggunakan pre test dan post test. Pre test bertujuan untuk mengetahui kemampuan akademik awal kedua kelas sebelum mendapat perlakuan. Selanjutnya kelas eksperimen mendapat perlakuan dengan proses pembelajaran e- learning berbasis edmodo dan kelas kontrol mendapat perlakuan yang berbeda yaitu dengan proses pembelajaran konvensional yang menggunakan media pembelajaran power point. Setelah kedua kelas tersebut diberi perlakuan, kemudian dilakukan post test untuk mengetahui perbedaan komunikasi dari kelompok eksperimen dan kelompok kontrol.

Penelitian campuran merupakan pendekatan penelitian yang mengkombinasikan antara penelitian kualitatif dengan penelitian kuantitatif. Menurut pendapat ("[PDF] Sugiyono Metode Penelitian Kuantitatif Kualitatif Dan r d Free Download PDF" n.d.) menyatakan bahwa metode penelitian kombinasi (mixed methods) adalah suatu metode penelitian yang mengkombinasikan atau menggabungkan antara metode kuantitatif dengan metode kualitatif untuk digunakan secara bersama-sama dalam suatu kegiatan penelitian, sehingga diperoleh data yang lebih komperehensif, valid, reliable, dan objektif. Dalam pengumpulan datanya peneliti melakukannya secara bersamaan baik data kuantitatif yang berupa hasil belajar serta data kualitatif yang berupa aktivitas belajar.

\section{HASIL DAN PEMBAHASAN}

Berdasarkan hasil pengujian tes awal (pre-test) kelas eksperimen maupun kelas kontrol adalah kedua kelas tersebut bersifat homogen, berdistribusi normal, kemampuan awal kedua kelas tersebut tidak berbeda secara signifikan. Hasil tes awal (pre-test) sangat membantu untuk melihat perkembangan komunikasi matematika setelah diberikan perlakuan pembelajaran,setelah melakukan pembelajaran baik kelas eksperimen maupun kelas kontrol selanjutnya adalah melakukan tes akhir (post-test). 
Penggunaan edmodo dapat membantu mengembangkan kompetensi kemampuan menggunakan media, kolaborasi virtual dan pengelolaan kognitif yang sejalan dengan hasil penelitian (Gomez, Magrenan \& Orcos, 2015). Hal ini dilakukan dalam memanfaatkan ICT dari sumber-sumber yang ada disekitar seperti wifi, smartphone, komputer, laptop dan warnet seperti yang diungkapkan oleh (Shams-abadi, Ahmadi \& Mehrdad,2015)

Belajar dengan menggunakan edmodo
(daring) efektif dalam pembelajaran matematika karena memberikan pengalaman yang baik yaitu memudahkan mahasiswa dalam mengerjakan quiz online yang dapat dilakukan dari mana saja dan kapan saja, mudah memperoleh materi ajar dalam berbagi video, file, folder, komunikasi secara matematik (pendidik dengan peserta didik/ peserta didik dengan peserta didik) selama proses belajar mengajar dan mendapatkan umpan balik yang dapat membantu penilaian sehingga dosen dapat merekapitulasi nilai secara otomatis.

Sikap mahasiswa terhadap soal-soal yang diperoleh selama proses belajar mengajar menunjukkan sikap yang positif karena didalam aplikasi edmodo memfasilitasi proses belajar mengajar dalam mengerjakan soal-soal yang diberikan dan dapat mendiskusikan contoh soal dan latihan soal dengan (pendidik dengan peserta didik) atau (peserta didik dengan peserta didik) secara daring sehingga komunikasi lebih efektif, dan menghemat waktu, hal ini sejalan dengan pendapat (Alsaid, K. M, 2015) menyatakan bahwa edmodo dapat memfasilitasi dan meningkatkan komunikasi dan efesien dalam waktu pada saat diluar kelas (daring).

Uji normalitas dilakukan untuk mengetahui apakah data-data motivasi belajar dan hasil tes belajar yang diperoleh dari kelas eksperimen maupun kelas kontrol normal atau tidak. Pada penelitian ini, pengujian normalitas menggunakan uji chi kuadrat pada taraf signifikan 0.05 .

Pada table diatas ditunjukkan nilai $\mathrm{X}^{2}$ hitung dan $\mathrm{X}^{2}$ Tabel untuk uji normalitas data kelas eksperimen dan kelas kontrol. Untuk kelas eksperimen diperoleh nilai $\mathrm{X}^{2}$ hitung 0,919 dan kelas kontrol diperoleh nilai $\mathrm{X}^{2}$ hitung 1,312 kedua nilai lebih kecil dari $\mathrm{X}^{2}$ tabel $\left(\mathrm{X}^{2}\right.$ hitung $<\mathrm{X}^{2}$ Tabel).
Berdasarkan analisis tersebut, dapat disimpulkan bahwa data pada penelitian ini untuk kemampuan komunikasi matematika kelas eksperimen dan kelas kontrol berdistribusi normal.

Pengujian homogenitas pada penelitian ini yaitu dengan menggunakan uji homogenitas $F_{\max }$ dari Hartley-Pearson, yaitu dengan membandingkan varians terbesar dan varians terkecil pada dua kelas yang dijadikan kelas eksperimen dan kelas control. Berdasarkan hasil pengujian homogenitas diperoleh $\mathrm{F}_{\text {hitung }}$ sebesar 2,075 dan $\mathrm{F}_{\text {tabel }}$ sebesar 1,860 . Berdasarkan nilai yang diperoleh bahwa $F_{\text {hitung }}>F_{\text {tabel }}$ maka disimpulkan bahwa data tersebut homogen atau varians dari kelas eksperimen dan kelas kontrol adalah tidak homogen.

Berdasarkan hasil perhitungan nilai $F_{\text {hitung }}=2,075$ pada taraf signifikan $\alpha=0,05$, sehingga disimpulkan $F_{\text {hitung }}>F_{\text {tabel }}$. Hal ini menunjukkan bahwa sampel tidak homogen.

Setelah dilakukan perhitungan uji prasyarat dan data terbukti normal dan tidak homogen, maka analisis dilanjutkan dengan pengujian hipotesis. Pengujian hipotesis dilakukan untuk membuktikan kebenaran atau menjawab hipotesis yang dipaparkan dalam penelitian ini. Uji hipotesis yang digunakan dalam penelitian ini adalah uji $t$ sampel independent. Digunakan uji $\mathrm{t}$ sampel independent karena sampel yang digunakan dalam penelitian ini tidak saling berhubungan, artinya sampel yang satu bukan merupakan bagian dari kelas yang satunya lagi. Akan tetapi, sampel yang digunakan adalah 2 kelas yang berbeda dengan mahasiswa yang juga berbeda. Tidak ada hubungan untuk sampel dari kedua kelas tersebut.

Hasil pengujian hipotesis dengan menggunakan uji $\mathrm{t}$ sampel independent diperoleh $t_{\text {hitung }}$ sebesar $=7,142$ dan nilai $t_{\text {tabel }}$ sebesar 2,00. Hal ini terlihat bahwa nilai $t_{\text {hitung }}$ $=7,142>t_{\text {tabel }}=2,00$ sehingga dapat disimpulkan bahwa $\mathrm{H}_{\mathrm{a}}$ diterima dan $\mathrm{H}_{0}$ ditolak yaitu ada perbedaan kemampuan komunikasi mahasiswa secara signifikan antara mahasiswa yang diajar dengan media edmodo dan mahasiswa yang tidak diajar dengan media edmodo. Hal ini menunjukkan bahwa kemampuan komunikasi mahasiswa yang 
diajar dengan media edmodo berbeda dengan kemampuan komunikasi mahasiswa yang tidak diajar dengan media edmodo.

Kemampuan komunikasi mahasiswa terlihat pada pengkategorisasian nilai untuk kedua kelas yaitu kelas eksperimen dan kelas Kontrol. Kategorisasi nilai tersebut, diperoleh dari hasil analisis deskriptif dimana pada analisis ini menunjukkan rata-rata kemampuan komunikasi yang diperoleh mahasiswa untuk kedua kelas yaitu kelas yang diajar dengan media edmodo dengan kelas yang tidak diajar dengan media edmodo. Nilai rata-rata yang diperoleh untuk kedua kelas yaitu kelas eksperimen dan kelas kontrol memiliki perbedaan.

Berdasarkan hasil analisis deskriptif, pada kelas yang diajar dengan media edmodo menunjukkan bahwa kemampuan komunikasi berada pada kategori sangat tinggi dengan frekuensi 23 dan presentase $76,66 \%$ sedangkan pada kelas yang tidak diajar dengan media edmodo, mahasiswa berada pada kategori tinggi dengan frekuensi 26 dan presentase $86,66 \%$. Begitupun dengan nilai rata-rata untuk setiap mahasiswa pada masing-masing kelas tersebut yang ditunjukkan dari hasil analisis deskriptif memiliki perbedaan.

Berdasarkan hasil penelitian yang dijelaskan, dapat disimpulkan atau secara umum kedua kelas memiliki kemampuan komunikasi berbeda, pada kelas yang diajar dengan media edmodo dan yang tidak diajar dengan media edmodo.

Hasil penelitian menunjukkan bahwa ada perbedaan yang signifikan kemampuan komunikasi matematika antara mahasiswa yang diajar dengan media edmodo dan mahasiswa yang tidak diajar dengan media edmodo. Hal ini berdasarkan pada hasil analisis uji $\mathrm{t}$ sampel independent dimana diperoleh nilai thitung yang lebih besar dibandingkan dengan nilai $t_{\text {tabel }}$. Berdasarkan hasil tersebut, maka pengambilan kesimpulan hipotesis yaitu $\mathrm{H}_{\mathrm{a}}$ diterima dan $\mathrm{H}_{0}$ ditolak. Dengan kata lain, ada perbedaan yang signifikan kemampuan komunikasi antara kelas yang diajar dengan media edmodo dengan kelas yang tidak diajar dengan media edmodo. Telah dijelaskan sebelumnya bahwa nilai rata-rata kemampuan komunikasi yang diperoleh mahasiswa untuk kedua kelompok/kelas tersebut pada dasarnya memiliki perbedaan dan rata-rata berada pada kategori tinggi.

Media edmodo adalah platform media sosial yang sering digambarkan sebagai facebook untuk sekolah dan dapat berfungsi lebih banyak lagi sesuai dengan kebutuhan. Edmodo merupakan aplikasi yang menarik bagi dosen dan mahasiswa dengan elemen sosial yang menyerupai facebook, sehingga mahasiswa lebih berminat untuk mengikuti proses pembelajaran. Edmodo yang juga berbasis kolaborasi merupakan aplikasi yang cukup aman digunakan oleh dosen dan mahasiswa. Seorang dosen, kampus, dapat dengan mudah mengelola sebuah system yang menyediakan fitur terbaik dan praktis menghilangkan kecemasan kita terhadap aktivitas yang biasa mahasiswa lakukan dengan internet khususnya facebook. Dengan platform ini akan lebih mudah untuk memonitor interaksi mahasiswa dalam edmodo learning environment. Tidak ada yang bisa msuk ke ruang tanpa undangan, dan mahsiswa tidak dapat menggunakannya untuk berhubungan dengan orang asing seperti yang terjadi di facebook, dan dapat dengan mudah mengetahui jika ada pelanggaran/penyusup/orang asing yang terdaftar di kelas yang dikelola dengan edmodo.

Edmodo seperti alat bantu belajar lainnya, bisa menjadi hanya sebuah platform online untuk mendorong pembelajaran dosen, atau dapat menjadi cara lebih kreatif untuk melibatkan para mahasiswa dalam pembelajaran kolaboratif dan kognisi terdistribusi. Edmodo bukanlah jawaban untuk setiap kelas tetapi yang terpenting adalah platform ini memberikan aspek penting dari sebuah lingkungan belajar yang positif. Platform ini memberikan mahasiswa jalur untuk berinteraksi dengan rakan-rekan mereka dan dosen mereka dalam suasana akademis. Lebih jauh lagi penggunaan platform ini dapat mengajarkan mahasiswa untuk bagaimana berperilaku secara online dan bertanggungjawab dalam mengatur kegiatan belajar mereka dengan system yang keamanannya terjamin.

Pada hakikatnya platform ini adalah mudah dipelajari dan mudah digunakan terutama bagi para dosen yang menganggap dirinya berada di luar basis pengetahuan 
teknologi yang berkembang saat ini. Edmodo menyediakan lingkungan dimana mengajar dan belajar dapat menghasilkan kegembiraan mahasiswa, mahasiswa menjadi lebih mandiri, tanpa melupakan standar pengukuran keberhasilan mahasiswa. Tidak dapat dipungkiri bahwa akan menyukai pembelajaran lewat platform ini, dan ketika mahasiswa merasa keinginan mereka untuk dapat mengatasi materi baru dan sulit akan mengingkat. Edmodo adalah salah satu cara untuk membangun semangat mahasiswa untuk belajar. Faktor-faktor tersebut diatas menunjukkan bahwa mahasiswa memiliki kemampuan komunikasi yang baik dalam mengikuti pembelajaran matematika melalui media edmodo.

Hasil penelitian ini di dukung oleh penelitian sebelumnya yang dilakukan oleh Ari Sudibjo Wasis dkk (2015) yang menunjukkan bahwa penggunaan media pemebalajaran edmodo memberikan pengaruh yang lebih baik dalam meningkatkan kemampuan komunikasi, dimana mahasiswa memiliki kemampuan komunikasi yang tinggi untuk belajar dengan presentase indikator respons setuju sebesar $70 \%$.

Berdasarkan penelitian yang telah dilakukan maka dapat disimpulkan bahwa ada perbedaan kemampuan komunikasi yang signifikan antara mahasiswa kelas yang diajar dengan media edmodo dan mahasiswa yang tidak diajar dengan media edmodo.

Hal ini disebabkan oleh beberapa faktor yang mempengaruhi yaitu faktor internal dan faktor eksternal. Dimana untuk faktor internal yaitu dari mahasiswa itu sendiri. Diantaranya adalah kemampuan komunikasi mahasiswa yang sangat mempengaruhi respon pada saat pembelajaran berlangsung. Sedangkan untuk faktor eksternal, yaitu waktu pembelajaran yang sangat kondusif. Hal ini sejalan dengan Sudjana (2009:22) yang mengatakan bahwa hasil belajar yang dicapai mahasiswa dipengaruhi oleh dua faktor utama yaitu faktor dari dalam diri mahasiswa, meliputi kemampuan yang dimilikinya, motivasi belajar, minat dan perhatian, sikap dan kebiasaam belajar, ketekunan, sosial ekonomi, faktor fisik dan psikis dan faktor yang datang dari luar diri mahasiswa atau faktor lingkungan. Dimana kemampuan komunikasi mahasiswa yang diajar dengan media edmodo menunjukkan ketertarikan dan semangat yang tinggi dibandingkan yang tidak diajar dengan media edmodo.

Ditinjau dari faktor internal tersebut yaitu kemampuan komunikasi pada saat pembelajaran dengan menggunakan media edmodo, terlihat bahwa kebanyakan mahasiswa sangat antusias pada saat belajar. Mahasiswa cenderung sangat memperhatikan materi yang dijelaskan. Dengan kata lain, mahasiswa sangat aktif.

\section{SIMPULAN DAN SARAN}

Berdasarkan penelitian yang telah dilakukan, adapun kesimpulan yang dipaparkan sebagai berikut:

1. Kemampuan Komunikasi Matematika pada matakuliah pendalaman materi matematika yang diajar dengan media edmodo di kelas 2B41 PGSD Universitas Quality masingmasing berada pada kategori sangat tinggi. Sedangkan kemampuan komunikasi matematika pada matakuliah pendalaman materi matematika yang tidak diajar dengan media edmodo di kelas 2B42 PGSD Universitas Quality masing-masing berada pada kategori tinggi.

2. Penggunaan media edmodo efektif terhadap kemampuan komunikasi matematika pada matakuliah pendalaman materi matematika kelas B41 PGSD Universitas Quality.

\section{UCAPAN TERIMAKASIH}

Terima kasih kami ucapkan kepada Kemenristekdikti atas penyediaan dana yang diberikan kepada kami melalui hibah penelitian dosen pemula, sehingga kami dapat menyelesaikan penelitian ini dengan baik.

\section{DAFTAR PUSTAKA}

Basori, Basori. 2013. "PEMANFAATAN SOCIAL LEARNING NETWORK "EDMODO" DALAM MEMBANTU PERKULIAHAN TEORI BODI OTOMOTIF DI PRODI PTM JPTK FKIP UNS." JIPTEK: Jurnal Ilmiah Pendidikan Teknik dan Kejuruan 6 (2). https://doi.org/10.20961/jiptek.v6i2.12562.

Listiani, Petti. 2014. "PENGARUH MODEL PROJECT BASED LEARNING TERHADAP KETERAMPILAN BERPIKIR KRITIS SISWA PADA MATA 
PELAJARAN TIK.” Other, Universitas Pendidikan Indonesia. http://repository.upi.edu/15303/10/S_KTP_1 006513_Appendix.pdf.

"National Council of Teachers of Mathematics (NCTM). (1989). Curriculum and Evaluation Standards for School Mathematics. Reston, VA: Author." n.d. Accessed October 1, 2018. https://www.researchgate.net/publication/345 89318_National_Council_of_Teachers_of_M athe

matics_NCTM_1989_Curriculum_and_evalu ation_standards_for_school_mathematics_Res ton_VA_Author.

Nu'man, Ahmad Zanin. 2014. "EFEKTIFITAS PENERAPAN ELEARNING MODEL EDMODO DALAM PEMBELAJARAN PENDIDIKAN AGAMA ISLAM TERHADAP HASIL BELAJAR SISWA (Studi Kasus: SMK Muhammadiyah 1 Sukoharjo)." Duta.Com 7 (1).http://journal.stmikdb.ac.id/index.php/du tacom/article/view/41.

"[PDF] Sugiyono Metode Penelitian Kuantitatif Kualitatif Dan $\mathrm{r}$ d - Free Download PDF." n.d. Accessed October $1,2018$. https://edoc.tips/download/sugiyonometode-penelitian-kuantitatif- kualitatifdan-r-d_pdf.

"Problem Solving Task Centres and the Professional Development of Mathematics Teachers." n.d. Accessed October 1, 2018. http://mathematicscentre.com/taskcentre/tc report.htm.

Putra, Solihin Riyandi, and Hendra Hidayat. n.d. "PENGEMBANGAN MEDIA PEMBELAJARAN EDMODO DENGAN VIDEO TUTORIAL PADA INSTALASI JARINGAN LAN PEER TO PEER JURUSAN TKJ DI SMKN I BUNUT,"6.

Setiawan, Johan, and PMWinarno. 2013. "Penerapan Sistem E-Learning Pada Komunitas Pendidikan Sekolah Rumah (Home Schooling)" IV (June).
Sudibyo, Ari, and Wasis -. 2013. "PENGGUNAAN MEDIA PEMBELAJARAN FISIKA DENGAN ELEARNING BERBASIS EDMODO BLOG EDUCATION PADA MATERI ALAT OPTIK UNTUK MENINGKATKAN RESPONS MOTIVASI DAN HASIL BELAJAR SISWA DI SMP NEGERI 4 SURABAYA." Inovasi Pendidikan Fisika 2 (3).http://jurnalmahasiswa.unesa.ac.id/index.p hp/inovasipendidikan-

fisika/article/view/4292.

"Sumber Daya Manusia Dan Produktivitas Kerja: Sedarmayanti - Belbuk.com." n.d. Accessed October 1, 2018. https://www.belbuk.com/sumber-daya manusia-dan-produktivitas-kerja-p13271.html.

Sumenge, Ariel Sharon. 2013. “ANALISIS EFEKTIFITAS DAN EFISIENSI PELAKSANAAN ANGGARAN BELANJA BADAN PERENCANAAN PEMBANGUNAN DAERAH (BAPPEDA) MINAHASA SELATAN." Jurnal EMBA: Jurnal Riset Ekonomi, Manajemen, Bisnis Dan Akuntansi 1 (3). https://ejournal.unsrat.ac.id/index.php/emba/a rticle/view/1941 
